\title{
KSZTAŁTOWANIE SIĘ CEN NIERUCHOMOŚCI ROLNYCH PO WSTAZPIENIU POLSKI DO UNII EUROPEJSKIEJ NA PRZYKŁADZIE AGENCJI NIERUCHOMOŚCI ROLNYCH OT OLSZTYN
}

\author{
DEVELOPMENT OF AGRICULTURAL REAL ESTATE PRICES \\ AFTER POLAND'S ACCESSION TO THE EUROPEAN UNION \\ ON THE EXAMPLE OF THE OLSZTYN BRANCH OF APA
}

\section{Krystyna KUROWSKA • Marek OGRYZEK • Hubert KRYSZK}

Uniwersytet Warmińsko-Mazurski w Olsztynie Wydział Geodezji, Inżynierii Przestrzennej i Budownictwa, Katedra Planowania i Inżynierii Przestrzennej ul. Prawocheńskiego 15, 10-720 Olsztyn krystyna.kurowska@uwm.edu.pl•marek.ogryzek@uwm.edu.pl•hubert.kryszk@uwm.edu.pl

Zarys treści: Po wejściu Polski do Unii Europejskiej obserwujemy wzmożone zainteresowanie nabywaniem nieruchomości rolnych zarówno przez indywidualnych rolników, jak i przez podmioty niezwiązane wcześniej z rolnictwem. Na kształtowanie cen rynkowych nieruchomości rolnych w ostatnich latach ma wpływ ograniczona podaż gruntów rolnych oraz uwarunkowania zewnętrzne związane z funkcjonowaniem polskiego rolnictwa w warunkach gospodarki europejskiej, w szczególności system dopłat do gruntów rolnych.

W artykule dokonano analizy sprzedaży nieruchomości rolnych na rynku państwowym (z zasobu Agencji Nieruchomości Rolnych) oraz prywatnym. Dane pozyskano z Głównego Urzędu Statystycznego w odniesieniu do lat 2005-2013 oraz z Agencji Nieruchomości Rolnych OT Olsztyn od roku 2004. Przeprowadzono również analizę zróżnicowania przestrzennego uzyskiwanych cen transakcyjnych na poziomie województw. Jak potwierdziły wyniki badań, rynek nieruchomości rolnych w Polsce w coraz większym stopniu uzależniony jest od czynników zewnętrznych.

Słowa kluczowe: nieruchomości rolne niezabudowane, ceny transakcyjne, rynek nieruchomości, Agencja Nieruchomości Rolnych.

\section{Wprowadzenie}

Przestrzeń jest dobrem rzadkim i jest ograniczona. Oznacza to, że powinniśmy racjonalnie nią gospodarować. Ograniczoność przestrzeni ma bardzo duży wpływ na kształtowanie się cen nieruchomości gruntowych. Obszary wiejskie są szczególnie ważne, bo oprócz tego, że odbywają się na nich cykle produkcyjne, pełnią również wiele funkcji pozaprodukcyjnych (Wilkin 2014, s. 118), stanowiąc dobro publiczne. Zgodnie z art. 46 ustawy Kodeks Cywilny z dnia 23 kwietnia 1964 r. nieruchomościami rolnymi (gruntami rolnymi) są nieru- 
chomości, które są lub mogą być wykorzystywane do prowadzenia działalności wytwórczej w rolnictwie w zakresie produkcji roślinnej i zwierzęcej, nie wyłączając produkcji ogrodniczej, sadowniczej i rybnej (Ustawa 1964). Nieruchomości rolne, które należą do tzw. nieruchomości niezurbanizowanych, zlokalizowanych głównie na obszarach wiejskich, traktowane są również jako forma inwestycji. Od czasu wejścia Polski do Unii Europejskiej obserwujemy wzmożone zainteresowanie nabywaniem nieruchomości rolnych. Jednak intensywny rozwój rynku nieruchomości w Polsce datuje się już znacznie wcześniej. Jako przełomową datę traktuje się 5 grudnia 1989 r., czyli pojawienie się ustawowych regulacji dotyczących wolnego obrotu nieruchomościami (Foryś i Putek-Szeląg 2006, s. 116).

W Polsce rynek nieruchomości rolnych obejmuje rynek państwowy oraz rynek prywatny, nazywany inaczej lokalnym czy międzysąsiedzkim. Istotnym wydaje się być obrót ziemią rolną, będącą w zasobie Agencji Nieruchomości Rolnych, który tworzą byłe grunty Państwowego Funduszu Ziemi (PFZ) oraz grunty byłych Państwowych Gospodarstw Rolnych. Po 1989 roku Agencja Własności Rolnej Skarbu Państwa, dzisiejsza Agencja Nieruchomości Rolnych (ANR) przejęła 4 mln 740 tys. ha ziemi. Na koniec 2014 r. w swoich zasobach posiadała ok. 1,5 mln ha gruntów, z czego ponad 1,1 mln ha pozostaje $w$ dzierżawie, do rozdysponowania jest ok. 265 tys. ha (Stan i perspektywy... 2015, s. 33). Najwięcej ziemi do rozdysponowania jest w województwach: zachodniopomorskim, lubuskim, dolnośląskim i warmińsko-mazurskim. Stan zasobów ANR w grudniu 2014 r. przedstawia ryc. 1.

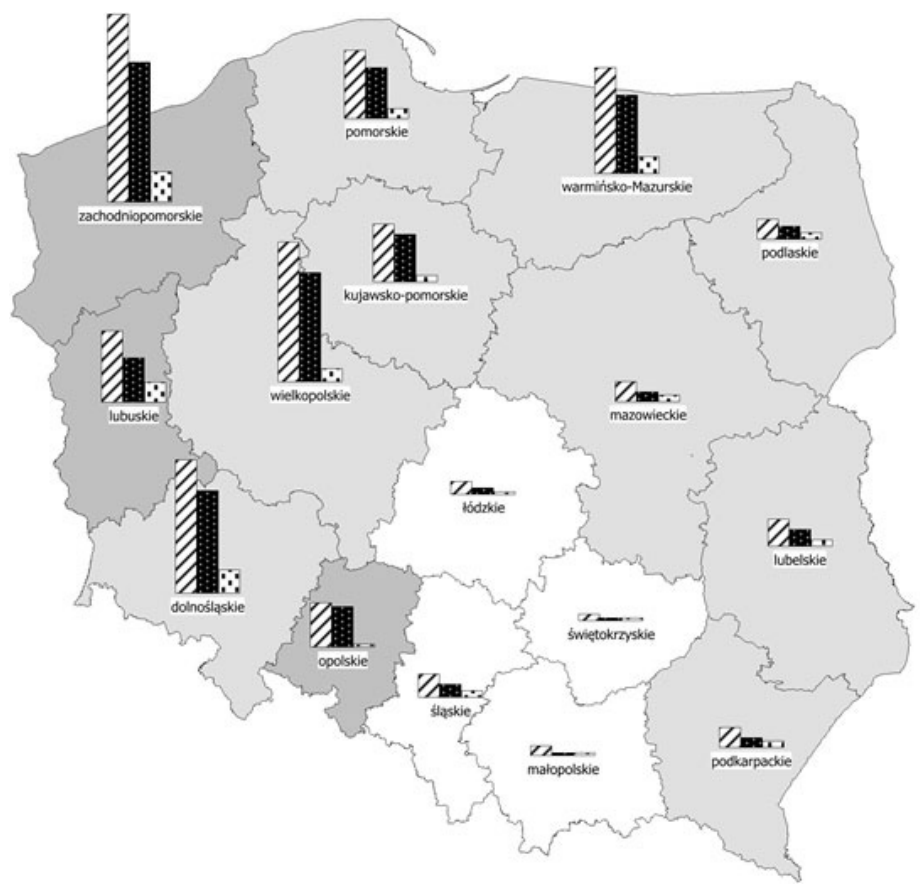

powierzchnia w tys. ha area in thous. he

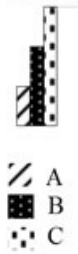

liczba transakcji/1000 gosp. number of trans./1,000 holdings $<50$

$50-100$

$>100$

Ryc. 1. Stan zasobów gruntów ANR, grudzień 2014

A - zasób ogółem, B - grunty w dzierżawie, C - grunty do rozdysponowania

Źródło: opracowanie własne na podstawie danych Agencji Nieruchomości Rolnych.

State of APA land resources as of December 2014

$A$ - total resource, $B$-land on lease, $C$-land to be distributed

Source: own elaboration based on data from Agricultural Property Agency. 
Najwięcej gruntów w zasobie ANR i do rozdysponowania nadal pozostaje w północnej i zachodniej części kraju. Tylko w 2013 r. zawarto ponad 14 tys. transakcji kupna-sprzedaży gruntów. Większość z nich miała miejsce w Polsce zachodniej: województwo zachodniopomorskie (1815 transakcji), lubuskie (1405) i warmińsko-mazurskie (1711). Bardzo dużo gruntów nadal pozostaje w dzierżawie.

Celem artykułu jest wykazanie prawidłowości występujących na rynku nieruchomości rolnych. Badania prowadzono pod kątem identyfikacji stanu aktualnego oraz perspektyw zmian w obrocie ziemią rolną w Polsce. W celu określenia tendencji zachowań na rynku ziemi rolnej w kraju w warunkach gospodarki europejskiej uwzględniono kształtowanie się cen nieruchomości rolnych w większości państw UE. Analizą objęto lata 2005-2013. Uwzględniono również poziom zróżnicowania przestrzennego cen transakcyjnych gruntów rolnych na poziomie województw (dane GUS za rok 2013).

Szczegółowa analiza opiera się na transakcjach gruntów rolnych niezabudowanych zbywanych z zasobu Agencji Nieruchomości Rolnych OT Olsztyn od 2004 r., czyli od wstąpienia Polski do Unii Europejskiej. Na potrzeby analiz transakcje zostały zgrupowane w trzech przedziałach powierzchniowych: 1-5 ha, 5-20 ha i powyżej 20 ha. Proponowane przedziały są ściśle związane z grupą potencjalnych nabywców. Odrzucono wszystkie transakcje dotyczące nieruchomości poniżej 1 ha. Przedmiotem analiz były transakcje sprzedaży nieruchomości gruntowych niezabudowanych, których przeznaczenie według planów zagospodarowania przestrzennego (miejscowy plan zagospodarowania przestrzennego lub studium uwarunkowań i kierunków zagospodarowania przestrzennego gminy) określone było jako grunty rolne.

Na potrzeby artykułu zastosowano metodę monograficzną w odniesieniu do przeglądu literatury, przepisów prawnych oraz dokumentów regulujących zasady kształtowania się cen nieruchomości rolnych niezabudowanych oraz cech mających wpływ na ich wartość rynkową. Dodatkowo przeprowadzono analizę porównawczą między średnimi cenami transakcyjnymi uzyskiwanymi na rynku prywatnym a cenami gruntów rolnych będących przedmiotem sprzedaży z zasobu ANR. Materiał opracowano metodą opisową, porównawczą i statystyczną z wykorzystaniem techniki tabelarycznej i graficznej.

Do podjęcia problemu badawczego skłoniło wzmożone zainteresowanie nieruchomościami rolnymi w ostatnich latach oraz przemiany struktury przestrzennej obszarów wiejskich. Rozważania zostały przeprowadzone w aspekcie poznania preferencji zachowań na rynku nieruchomości w warunkach gospodarki europejskiej.

\section{Czynniki wpływające na wartość nieruchomości rolnych}

W maju 2016 r. upływa okres przejściowy na zakup ziemi przez cudzoziemców w Polsce. W związku z powyższym przewiduje się dalszy wzrost cen gruntów rolnych wraz ze wzmożonym zainteresowaniem w nabywaniu nieruchomości rolnych. Ceny ziemi rolnej w poszczególnych państwach członkowskich Unii Europejskiej są wyraźnie zróżnicowane (por. ryc. 2). Wydawało się, iż w krajach tzw. starej Unii ceny te powinny się wyrównać, ale w praktyce tak się nie stało (Pałasz 2007). Na podstawie opublikowanych przez Instytut Ekonomiki Rolnictwa i Gospodarki Żywnościowej wyników badań (Stan i perspektywy... 2015, s. 35) kraje UE można podzielić pod względem cen gruntów rolnych na trzy grupy. Pierwszą z nich stanowią kraje starej Unii, w których dominują transakcje wolnorynkowe 
i w większości z nich średnie ceny ziemi od wielu lat są bardzo wysokie. Wyjątek stanowi Francja i Szwecja, w przypadku których ceny ziemi rolnej są na podobnym poziomie jak w Polsce. We Francji przesądza o tym stabilny system nadzoru obrotem ziemią rolną (SAFER). Ceny ziemi są tam skorelowane z sytuacją gospodarczą kraju. Do drugiej grupy zaliczane są głównie kraje nadbałtyckie, w tym Polska, które do UE przystąpiły w 2004 r. W grupie tej dominuje również wolnorynkowy (krajowy) obrót ziemią i w większości tych krajów odnotowano znaczny wzrost cen gruntów rolnych. Ostatnią grupę stanowią kraje z wysoką dynamiką wzrostów cen ziemi, m.in.: Czechy, Słowacja oraz Rumunia. Charakteryzują się one niekorzystną strukturą agrarną gospodarstw rolnych z dominującym udziałem małych powierzchniowo gospodarstw (np. Rumunia). Innym problemem jest niezakończony proces reprywatyzacji państwowych gruntów (np. Czechy i Słowacja). Wykres poniżej (ryc. 2) obrazuje średnie ceny transakcyjne uzyskiwane za 1 ha w 2013 r. w wybranych krajach UE.

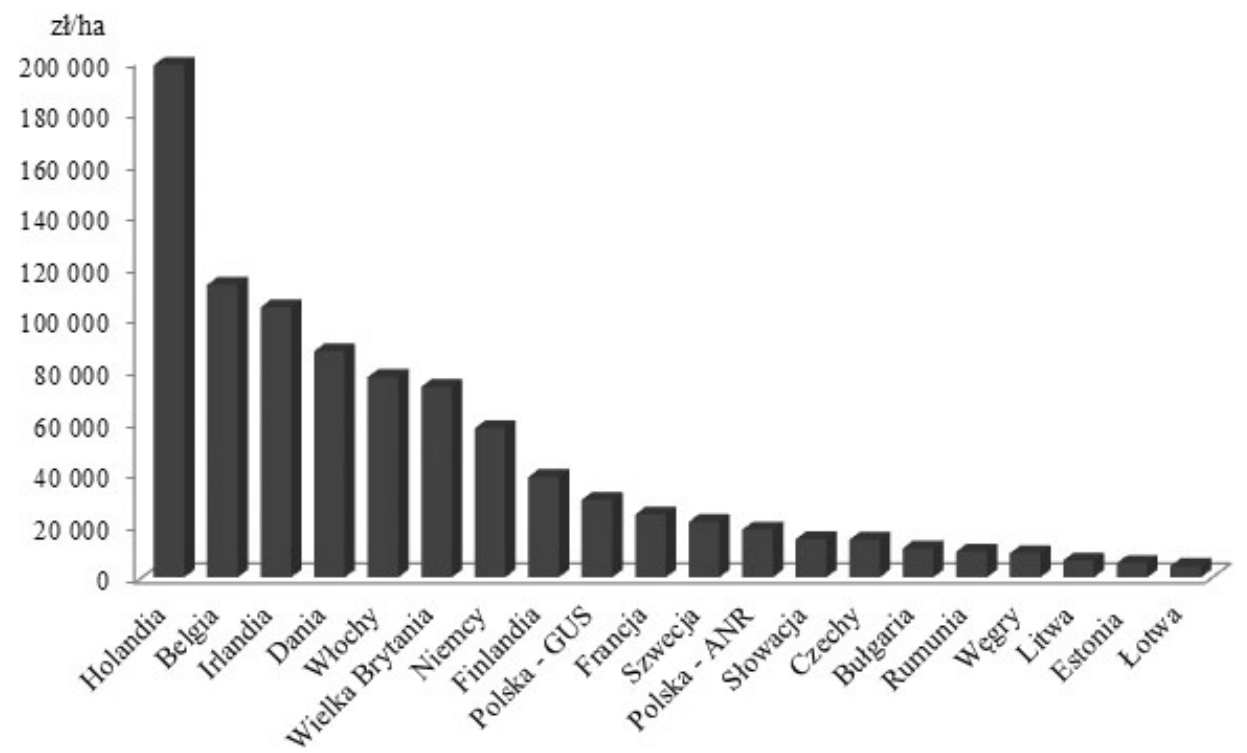

Ryc. 2. Średnie ceny transakcyjne w wybranych krajach UE w 2013 r.

Źródło: Instytut Ekonomiki Rolnictwa i Gospodarki Żywnościowej - Państwowy Instytut Badawczy, 2014.

Average transaction prices of agricultural land in selected EU countries in 2013

Source: Institute of Agricultural and Food Economics - National Research Institute, 2014.

W 2103 r. najwyższe średnie ceny transakcyjne - na poziomie ok. 200 tys. zł/ha - odnotowano w Holandii, a najniższe na Łotwie ok. 5 tys. zł/ha. W Polsce w tym okresie średnie ceny transakcyjne kształtowały się w przedziale 20-25 tys. zt/ha, w zależności od zasobu, z którego zbywana była nieruchomość (zasób ANR lub obrót prywatny). Według danych ANR (I kwartał 2015) w niektórych regionach kraju przeciętne ceny transakcyjne osiągały ok. 40 tys. zł/ha. Poziom cen gruntów rolnych był kilku-, a nawet kilkudziesięciokrotnie niższy niż w Holandii czy innych krajach byłej 15-tki. Ponadto aktualna perspektywa finansowa Unii Europejskiej i zaplanowany duży udział subwencji na rolnictwo w budżecie 2014-2020 powinny sprzyjać rozwojowi tego sektora gospodarki oraz utrzymywać zainteresowanie zakupem ziemi w celu powiększania gospodarstw rodzimych. 
Na wartość nieruchomości rolnych wpływa wiele czynników, z których za najważniejsze uważa się: lokalizację, dogodność dojazdu, wartość użytkową (jakość bonitacyjną), ukształtowanie powierzchni, kulturę rolną, trudność uprawy, wielkość zanieczyszczeń środowiska, występowanie urządzeń melioracyjnych czy urządzeń infrastruktury utrudniającej agrotechnikę (Kurowska i in. 2014, s. 307). Wszystkie te cechy są uwzględniane przy określaniu wartości nieruchomości. W Polsce nie stwierdzono decydującej roli jakości gleb w kształtowaniu się ceny ziemi rolniczej. Wynika to ze zróżnicowania regionalnego oraz indywidualnych cech rynku lokalnego (Pietrzykowski 2011). Cena ziemi na rynku lokalnym będzie wzrastać w warunkach dużego na nią popytu przy ograniczonej podaży (Well 2003, s. 153). Coraz bardziej jest zauważalny wpływ czynników środowiskowych na cenę transakcyjną nieruchomości rolnych i jest on zróżnicowany w zależności od potencjalnego przeznaczenia nieruchomości rolnych. Jak dowodzi w swoich badaniach B. Kempa (2010), wyższe ceny uzyskiwano w odniesieniu do mniejszych nieruchomości rolnych z możliwością wykorzystania innego niż rolnicze, gdzie mały wpływ miały walory produkcyjne gleby. Wartość nieruchomości rosła wraz ze zmniejszeniem odległości od zwartej zabudowy, a malała w pobliżu składowisk odpadów. Korzystnie na cenę wpływało sąsiedztwo terenów objętych ochroną. W przypadku nieruchomości wykorzystywanych na cele rolnicze i leśne duży wpływ na wysoką wartość nieruchomości rolnych miała jednak bonitacja gleby (Kempa 2010). Zróżnicowanie średnich cen transakcyjnych z uwzględnieniem klas bonitacyjnych obrazuje ryc. 3.

Do analiz przyjęto dane od 2006 r., gdyż dane za wcześniejsze lata były niepełne. Na podstawie wykresu (ryc. 3) jednoznacznie można stwierdzić znaczący wzrost wartości nieruchomości rolnych, głównie od 2012 r. Zjawisko to jest szczególnie widoczne w przypadku najlepszych gruntów rolnych, do których według klasyfikacji GUS zaliczamy klasę I, II i IIla.

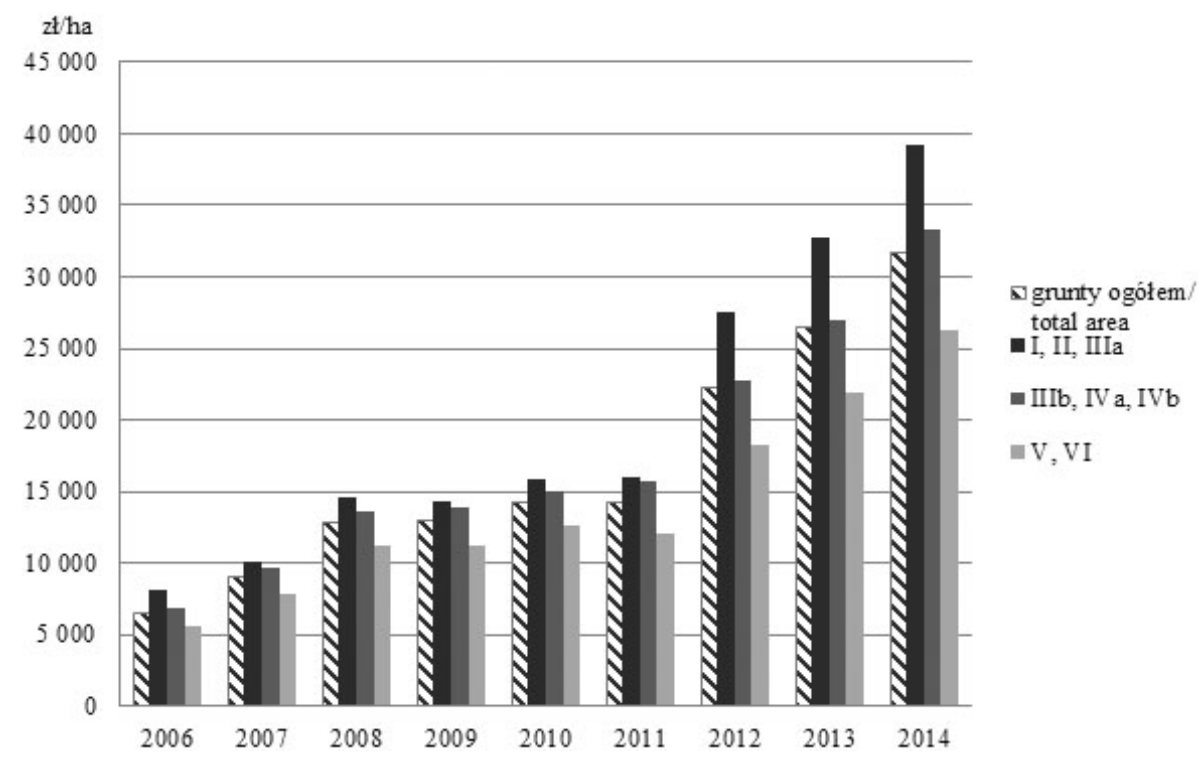

Ryc. 3. Średnia cena 1 ha z uwzględnieniem klas gruntów Źródło: opracowanie własne na podstawie danych GUS. Average price of 1 ha regarding land classes Source: own elaboration based on the CSO. 
Cena nieruchomości rolnych w znacznym stopniu jest też zależna od sąsiedztwa, szczególnie w przypadku nieruchomości rolnych z możliwością wykorzystania na inne cele. Uzyskiwane ceny sprzedaży coraz częściej zależą od czynników pozarolniczych. Należą do nich uwarunkowania zewnętrzne, w tym gospodarowanie gruntami rolnymi w ramach gospodarki europejskiej. Realizacja Wspólnej Polityki Rolnej przyczynia się do zmian struktury obszarowej gospodarstw (Wigier 2013, s. 3) oraz znacząco wpływa na wzrost cen nieruchomości rolnych. W kontekście europejskiej polityki rolnej rozszerzył się również zakres czynników mających wpływ na uzyskiwane ceny transakcyjne zbywanych nieruchomości rolnych (Foryś i Putek-Szeląg 2008). System dopłat bezpośrednich do gruntów rolnych oraz możliwość pozyskania dofinansowania przez rolników w ramach PROW spowodował zainteresowanie gruntami rolnymi, co bezpośrednio przekłada się na wzrost ich cen. Należy zauważyć, iż w Polsce działa uproszczony system dopłat do gruntów rolnych, w którym obowiązuje jednakowa stawka płatności do każdego hektara ziemi rolnej pod warunkiem utrzymywania jej w dobrej kulturze rolnej. Oznacza to, że wysokość dopłat bezpośrednich jest taka sama i nie ma na nią wpływu jakość gleby czy położenie nieruchomości (Kurowska i in. 2014). Ważnym czynnikiem wpływającym na wartość gruntów rolnych jest również położenie na terenach o niekorzystnych warunkach gospodarowania (na obszarach ONW). Potencjalni nabywcy są w stanie zapłacić więcej za grunty położone na obszarach ONW, gdyż niekorzystne uwarunkowania rekompensowane są przez dodatkowe środki finansowe, jako dopłaty wyrównawcze (Kocur-Bera i Dudzińska 2014, s. 59).

W Polsce obrót nieruchomościami rolnymi w dużym stopniu jest kontrolowany przez ANR. Przepisy prawa regulują zasady zbywania nieruchomości rolnych Skarbu Państwa oraz wprowadzają ograniczenia w ich nabywaniu. Ingerencja państwa przejawia się też w prawie pierwokupu ANR (Laskowska 2011, s. 153). Obrót ziemią rolną obejmuje wszelkie sytuacje, które prowadzą do zmiany podmiotów gospodarczych w gospodarstwie rolnym (Maśniak 2011, p. 3). Efektem obrotu ziemią rolną jest zmiana jej właściciela lub użytkownika (Kozłowska-Burdziak 2013, s. 60). Zasady dysponowania mieniem Skarbu Państwa reguluje ustawa o gospodarowaniu nieruchomościami rolnymi Skarbu Państwa z dnia 19 października 1991 (Ustawa 1991). Podstawowym trybem sprzedaży nieruchomości rolnych będących w zasobie ANR jest ogólnodostępny przetarg. Sprzedaż odbywa się w drodze przetargu ograniczonego (dla rolników indywidualnych) lub nieograniczonego (dotyczy pozostałych zainteresowanych). Przetarg może odbyć się w formie licytacji ustnej bądź przetargu ofert pisemnych. Agencja najczęściej organizuje przetargi ustne, dzięki którym jest możliwe uzyskanie najwyższej ceny sprzedaży. W przetargu, jako uczestnicy mogą brać udział osoby fizyczne i osoby prawne (Rozporządzenie... 2009). Tymczasową formą rozdysponowania nieruchomości rolnych z zasobu ANR jest przekazanie w dzierżawę na warunkach i zasadach podobnych jak przy sprzedaży. Dzierżawa była podstawowym sposobem zagospodarowania gruntów zasobu w początkach działalności Agencji z uwagi na ówczesną dużą ofertę gruntów Skarbu Państwa i ograniczone możliwości finansowe ich potencjalnych nabywców (Nawrocki 2010, s. 173). Jednak zdecydowana większość dzierżawców traktuje tę formę gospodarowania jako przejściową (Marks-Bielska 2009). Dzierżawcy nieruchomości rolnych po upływie 3 lat nabywają prawo pierwszeństwa w nabyciu dzierżawionych nieruchomości. W większości przypadków zakup gruntów w ramach pierwszeństwa w nabyciu charakteryzuje się niższymi cenami transakcyjnymi (Kryszk i in. 2014). Szczegółowe analizy zostały przeprowadzone na przykładzie transakcji kupna sprzedaży z Zasobu ANR OT Olsztyn oraz GUS. 


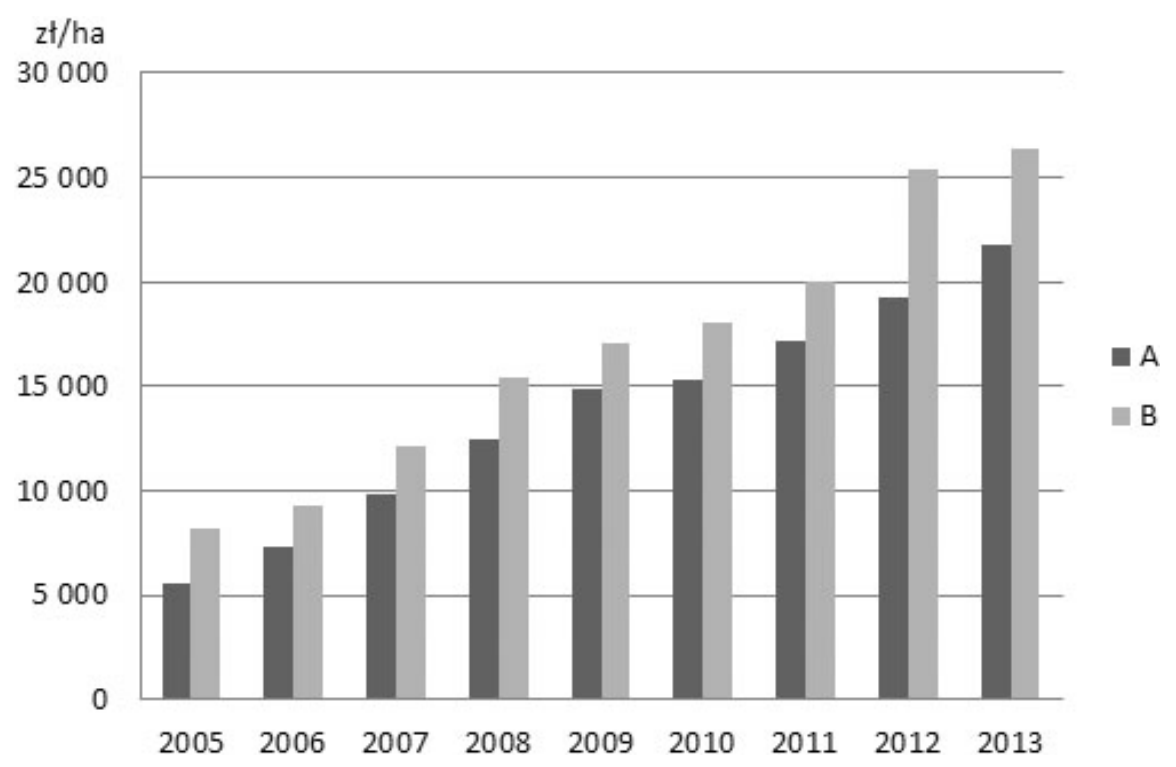

Ryc. 4. Przeciętne ceny gruntów rolnych (zł/ha): $A-z$ zasobu ANR, B - w obrocie prywatnym Źródło: Opracowanie własne na podstawie GUS.

Average prices of arable land (PLN/ha): A - of APA resource, B - in private turnover Source: own elaboration based on the CSO.

W analizowanym okresie, tj. w latach 2005-2013, odnotowano coroczny wzrost cen transakcyjnych nieruchomości rolnych (ryc. 4). Wartym uwagi jest fakt, że wystąpiły znaczne różnice w uzyskiwanych cenach transakcyjnych pomiędzy rynkiem państwowym a rynkiem prywatnym. Największą odnotowano w 2005 r. (na poziomie 45\%), a od 2006 r. różnica ta ma tendencję do stabilizacji i kształtuje się na poziomie 25-30\%. Wynika to z faktu, że w Polsce obrót nieruchomościami rolnymi, poza sprzedażą z zasobu ANR, jest ograniczony. Stabilizacja w ostatnim okresie na rynku państwowym jest wynikiem prowadzonej polityki gospodarowania nieruchomościami rolnymi pozostającymi w zasobie ANR, tj. przeznaczenia do sprzedaży w latach 2012-2013 gruntów, które pochodziły z tzw. wyłączeń 30\% dzierżawionej powierzchni.

W związku z powyższym przeprowadzono szczegółową analizę zróżnicowania przestrzennego cen transakcyjnych uzyskiwanych na rynku prywatnym i państwowym w roku 2013 (ryc. 5). Jednoznacznie można stwierdzić duże zróżnicowanie uzyskiwanych cen w poszczególnych województwach. Największe dysproporcje w cenie ziemi z zasobu ANR względem obrotu prywatnego w 2013 r. dotyczyły województwa podlaskiego (ok. 10,6 tys. zł/ha) i wielkopolskiego (ok. 10,3 tys. zł/ha). Jedynie w trzech województwach: mazowieckim, opolskim i śląskim przeciętne ceny ziemi w obrocie prywatnym były niższe od sprzedawanych za pośrednictwem ANR. Jest to spowodowane brakiem gruntów w zasobie ANR.

Sprzedaż państwowych gruntów rolnych realizowana jest głównie na terenach północnej i zachodniej Polski, gdzie dominują działki o dużej powierzchni. Dalszy obrót tymi gruntami powoduje, że liczba transakcji na tych terenach jest również najwyższa. W centralnej i południowej Polsce obrót gruntami odbywa się na rynku prywatnym, gdzie dominuje podaż działek niewielkich powierzchniowo. 


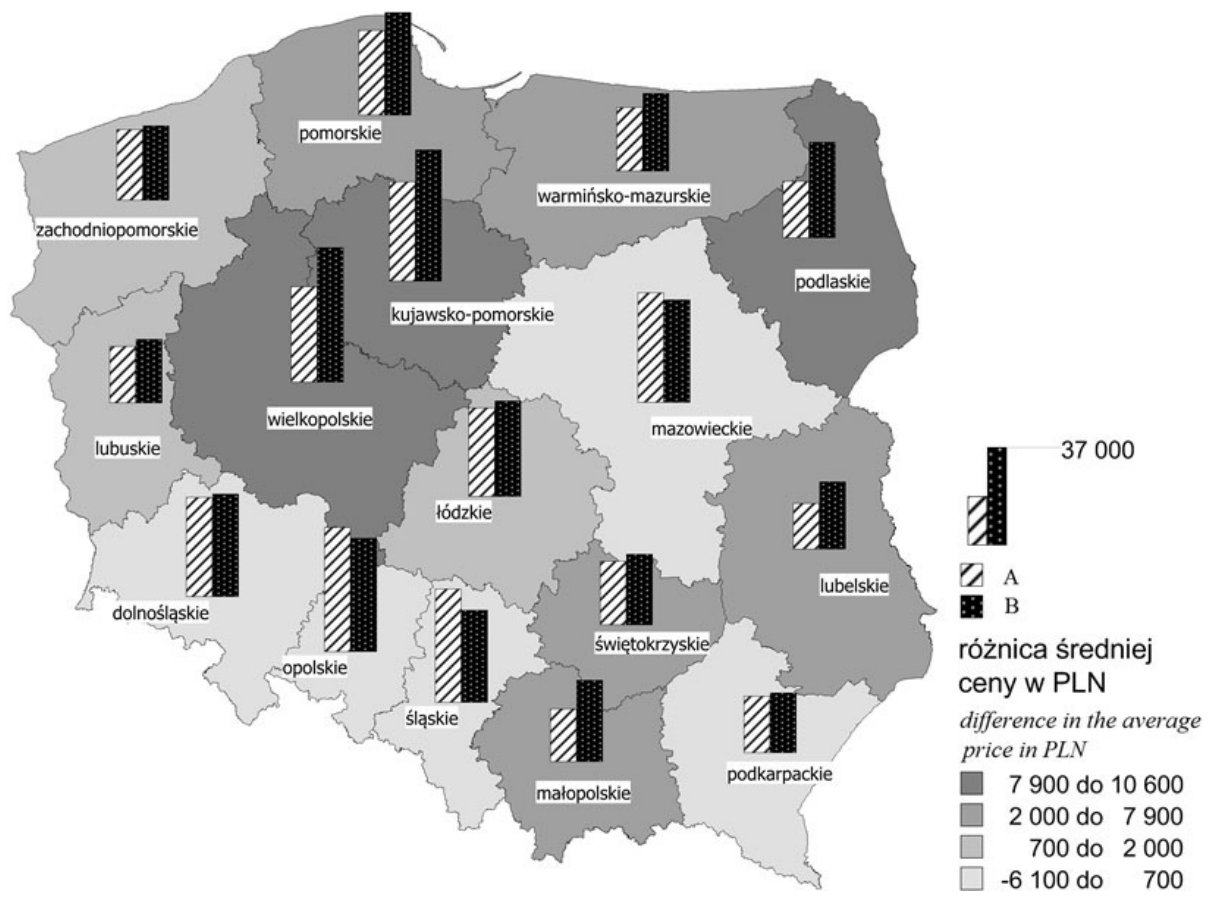

Ryc. 5. Regionalne zróżnicowanie cen ziemi na rynku prywatnym i państwowym w 2013 r. A - średnia cena 1 ha wg ANR, B - średnia cena 1 ha wg GUS

Źródło: Instytut Ekonomiki Rolnictwa i Gospodarki Żywnościowej - Państwowy Instytut Badawczy, grudzień 2014. Regional variation in land prices on private and state markets in 2013

A -average price of 1 ha by the APA, B-average price of 1 ha by the CSO

Source: Institute of Agricultural and Food Economics - National Research Institute, 2014.

\section{Kształtowanie się cen ziemi rolnej w województwie warmińsko-mazurskim}

W ramach ANR OT Olsztyn w okresie od 1 maja 2004 r. do 31 grudnia 2014 r. zostało zawartych 6946 transakcji w ramach przetargów ustnych ograniczonych, nieograniczonych oraz pierwszeństwa w nabyciu. Na potrzeby badań transakcje podzielono na trzy przedziały powierzchniowe: 1-5 ha, 5-20 ha i powyżej 20 ha. Jak wynika z informacji uzyskanych z ANR, proponowane przedziały powierzchniowe są ściśle związane z grupą potencjalnych nabywców. W ramach analiz odrzucono wszystkie transakcje dotyczące nieruchomości poniżej 1 ha. Informacje na temat sprzedaży nieruchomości rolnych niezabudowanych od 1 maja 2004 r. przedstawia tabela 1.

Przedmiotem analiz były transakcje sprzedaży nieruchomości gruntowych niezabudowanych, których stan planistyczny, według obowiązującego miejscowego planu zagospodarowania przestrzennego lub studium uwarunkowań i kierunków zagospodarowania przestrzennego, określony był jako grunty rolne. Na podstawie bazy transakcji prowadzonej przez Agencję ustalono, iż maksymalna powierzchnia sprzedanej nieruchomości wynosiła 481,84 ha (2007 r.). W analizowanym okresie łączna powierzchnia sprzedanych nieruchomości rolnych niezabudowanych wyniosła 88 277,2 ha. Jak wynika z analiz, ceny transakcyjne są zróżnicowane i zależą od formy sprzedaży oraz powierzchni sprzedawa- 
nych nieruchomości rolnych. Charakterystykę rynku nieruchomości gruntowych rolnych niezabudowanych pochodzących z zasobu ANR OT Olsztyn wyselekcjonowanych z bazy transakcji (powyżej 1 ha i poniżej 500 ha) z uwzględnieniem powierzchni zbywanych nieruchomości rolnych przedstawia ryc. 6.

Tabela 1. Charakterystyka transakcji nieruchomości rolnych niezabudowanych z zasobu ANR OT Olsztyn

\begin{tabular}{|c|c|c|c|c|c|}
\hline \multirow{2}{*}{$\begin{array}{c}\text { Rok } \\
\text { sprzedaży }\end{array}$} & \multicolumn{2}{|c|}{ Liczba transakcji } & \multicolumn{2}{c|}{ Sprzedana powierzchnia w ha } \\
\cline { 2 - 6 } & $\begin{array}{c}\text { ogółem powyżej } \\
\text { 1 ha }\end{array}$ & $\begin{array}{c}\text { w tym powyżej } \\
\mathbf{2 0} \text { ha }\end{array}$ & $\begin{array}{c}\text { ogółem powyżej } \\
\mathbf{1} \text { ha }\end{array}$ & średnia & maksymalna \\
\hline 2004 & 621 & 30 & 4492,20 & 7,23 & 221,16 \\
2005 & 492 & 27 & 3855,02 & 7,84 & 436,22 \\
2006 & 706 & 173 & 12772,81 & 18,09 & 351,94 \\
2007 & 841 & 149 & 12718,78 & 15,12 & 481,84 \\
2008 & 272 & 34 & 2684,76 & 9,87 & 99,46 \\
2009 & 416 & 57 & 4271,37 & 10,27 & 141,69 \\
2010 & 791 & 148 & 12758,12 & 16,13 & 367,36 \\
2011 & 807 & 147 & 10687,25 & 13,24 & 280,10 \\
2012 & 637 & 108 & 8572,56 & 13,46 & 235,77 \\
2013 & 754 & 113 & 8210,65 & 10,89 & 304,50 \\
2014 & 609 & 112 & 7253,68 & 11,91 & 473,57 \\
\hline
\end{tabular}

Źródło: Opracowanie własne na podstawie bazy ANR OT Olsztyn.

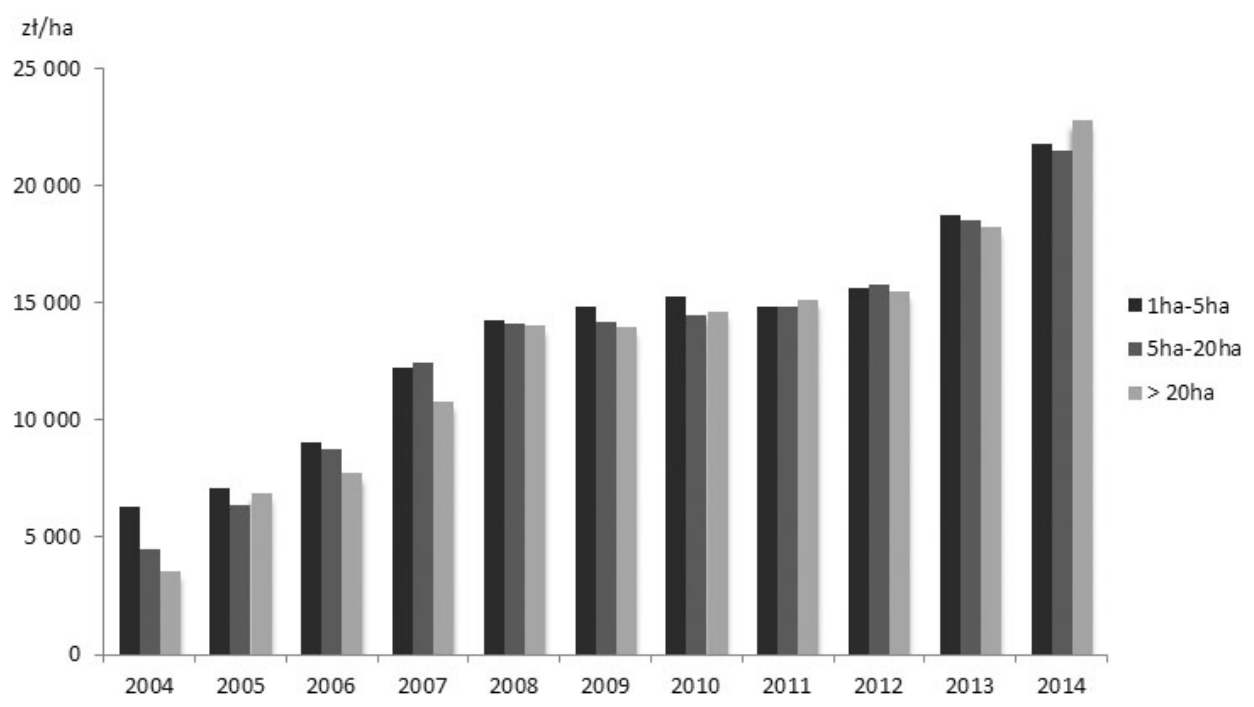

Ryc. 6. Średnie ceny transakcyjne gruntów rolnych niezabudowanych Źródło: Opracowanie własne na podstawie danych ANR OT Olsztyn. Average transaction prices of non built-up agricultural land

Source: own elaboration based on data from the Olsztyn branch of APA. 
W pierwszych latach członkostwa Polski w UE na terenie województwa warmińsko-mazurskiego, analogicznie do sytuacji w kraju i w większości nowych państw UE, odnotowano znaczny wzrost wartości ziemi rolnej. Do 2010 r. najwyższe średnie ceny wystąpiły w przypadku małych nieruchomości rolnych. Wynikało to z dużej podaży nieruchomości rolnych. Grunty rolne o większych powierzchniach (powyżej 5 ha) w dużej mierze były przedmiotem wieloletniej dzierżawy. W miarę upływu czasu dotychczasowi dzierżawcy nabywali dzierżawione nieruchomości w trybie bezprzetargowym w ramach pierwszeństwa w nabyciu. Sytuacja na rynku nieruchomości rolnych była w miarę stabilna w latach 2008-2012, kiedy odnotowano jednostajny wzrost wartości nieruchomości.

Od 2013 r. średnie ceny transakcyjne nieruchomości rolnych niezabudowanych znacznie wzrosły. Wynika to z prowadzonej polityki gospodarowania nieruchomościami rolnymi pozostającymi w zasobie ANR, tj. pojawienia się na rynku nieruchomości zbywanych z ANR na terenie województwa warmińsko-mazurskiego gruntów użytkowanych rolniczo, utrzymanych w dobrej kulturze rolnej, pochodzących z wyłączeń w ramach umów dzierżawy. Wzmożone zainteresowanie nabywaniem nieruchomości rolnych, szczególnie o większych powierzchniach (powyżej 5 ha), wynika również z kończącego się okresu przejściowego w nabywaniu nieruchomości przez cudzoziemców. Obecna sytuacja w rolnictwie zachęca również rolników indywidulanych do koncentracji gruntów (Zegar 2009), zwiększania powierzchni gospodarstw rolnych, co jest warunkiem uzyskania wyższych dochodów w prowadzonych gospodarstwach rolnych. Widoczne jest również silne oddziaływanie Wspólnej Polityki Rolnej na terenie Warmii i Mazur. Rynek gruntów rolnych do końca 2013 r. wspierany był również niskooprocentowanymi kredytami preferencyjnymi na zakup ziemi. Od 1 stycznia 2014 r. oprocentowanie wzrosło, ale niskie stopy procentowe, a co za tym idzie tańsze kredyty komercyjne, zmniejszały popyt na kredyty preferencyjne. Utrzymanie stóp procentowych na niskim poziomie w 2014 r. sprzyjało wzrostowi udziału tej formy współfinansowania zakupu ziemi.

\section{Wnioski}

Biorąc pod uwagę europejski rynek ziemi rolnej, w Polsce ceny gruntów rolnych kształtują się na średnim poziomie. Od 2004 r. obserwujemy znaczny wzrost wartości nieruchomości. W niektórych regionach kraju ceny wzrosły nawet o 400\%. Obserwując tendencje na rynku europejskim, przewiduje się dalszy wzrost wartości nieruchomości rolnych. W zasobie ANR na terenie województwa warmińsko-mazurskiego pozostaje nadal wiele gruntów rolnych do rozdysponowania. W 2014 r. oddział w Olsztynie dysponował jeszcze 170 tys. ha gruntów. Na podstawie przeprowadzonych analiz można wyciągnąć następujące wnioski:

- Od czasu wejścia Polski do UE i objęcia polskiego rolnictwa instrumentami Wspólnej Polityki Rolnej cena ziemi rolnej stale rośnie. Do powiększania już istniejących gospodarstw zachęcają rolników środki finansowe przewidziane na rolnictwo w ramach nowej perspektywy finansowej 2014-2020.

- W poszczególnych regionach (województwach) ceny gruntów rolnych są zróżnicowane. Wysokie ceny transakcyjne na rynku państwowym są warunkowane spadkiem podaży z zasobu ANR. W województwach, gdzie w zasobie ANR pozostają atrakcyjne grunty do sprzedaży (duże powierzchnie), odnotowuje się niższe różnice w stosunku do rynku prywatnego. 
- Zróżnicowanie przestrzenne uzyskiwanych cen transakcyjnych wynika również z dużego zróżnicowania przydatności gruntów rolnych do produkcji rolnej (ukształtowanie terenu, jakość gleb, stosunki wodne oraz klimat).

- Nie bez wpływu na kształtowanie się cen transakcyjnych gruntów rolnych w Polsce pozostaje również kończący się okres przejściowy na zakup ziemi przez cudzoziemców (maj 2016 r.).

- Przewidując tendencje rynku nieruchomości rolnych w Polsce należy spodziewać się wzmożonego zainteresowania wśród potencjalnych nabywców oraz dalszego wzrostu cen gruntów rolnych. Widoczny jest również coraz większy wpływ czynników zewnętrznych kształtujących poziom cen ziemi rolnej.

Artykuł opracowano w ramach przedsięwzięcia Zastosowanie technologii GIS do gospodarowania Zasobem Skarbu Państwa na przykładzie ANR OT Olsztyn, Umowa Nr 02/ SFKiW/2015.

\section{Literatura}

Foryś I., Putek-Szeląg E., 2006, Metody statystyczne w analizie transakcji gruntami rolnymi w województwie zachodniopomorskim na przykładzie zasobu Agencji Nieruchomości Rolnych, Zeszyty Naukowe Uniwersytetu Szczecińskiego, 450 (17), s. 117-128.

Foryś I., Putek-Szeląg E., 2008, Przesłanki inwestowania w nieruchomości rolne na przykładzie zasobów AWRSP i ANR w zachodniopomorskim, Studia i Materiały Towarzystwa Naukowego Nieruchomości, 16, 4, s. 37-48.

Kempa B., 2010, Czynniki środowiskowe a wartość użytków rolnych, Acta Scientiarum Polonorum, Administratio Locorum, 9 (1), s. 47-56.

Kocur-Bera K., Dudzińska M., 2014, Model cen nieruchomości rolnych na przykładzie województwa warmińsko-mazurskiego, [w:] S. Źróbek (red.), Analiza rynku i zarzq̨dzanie nieruchomościami, Towarzystwo Naukowe Nieruchomości, Olsztyn, s. 59-72.

Kozłowska-Burdziak M., 2013, Rola Agencji Nieruchomości Rolnych w obrocie ziemia rolniczq w Polsce, [w:] R. Marks-Bielska, R. Kisiel (red.), Rola Agencji Nieruchomości Rolnych w unowocześnianiu rolnictwa i obszarów wiejskich, Uniwersytet Warmińsko-Mazurski w Olsztynie, s. 51-72.

Kryszk H., Kurowska K., Ogryzek M., 2014, Analiza cen transakcyjnych nieruchomości gruntowych niezabudowanych będacych w zasobie ANR OT Olsztyn, Studia i Prace Wydziału Nauk Ekonomicznych i Zarządzania, 36, 1, s. 291-302.

Kurowska K. Kryszk H., Cymerman R., 2014, Identyfikacja czynników wpływajqcych na kształtowanie się cen transakcyjnych nieruchomości rolnych będqcych w zasobie ANR OT Olsztyn, Studia i Prace Wydziału Nauk Ekonomicznych i Zarządzania, 36, 1, s. 303-316.

Laskowska E., 2011, Inwestowanie na rynku gruntów rolnych w Polsce, Roczniki Nauk Rolniczych, Seria G, 98, 3, s. 150-159.

Marks-Bielska R., 2009, Nabywanie i dzierżawa nieruchomości rolnych w opiniach rolników z województwa warmińsko-mazurskiego, Zagadnienia Ekonomiki Rolnej, 4 (321), s. 153-164.

Maśniak J., 2011, Znaczenie polityki rolnej państwa rozwoju rynku ziemi rolniczej w Polsce, Roczniki Nauk Rolniczych, Seria G: Ekonomika Rolnictwa, 98 (3), s. 108-117. 
Nawrocki T., 2010, Gospodarowanie nieruchomościami zasobu własności rolnej Skarbu Państwa w działalności Agencji Nieruchomości Rolnych, Wieś i Rolnictwo, 3 (148), s. 167-178.

Pałasz L., 2007, Tendencje wzrostu cen ziemi rolnej, Acta Scientiarum Polonorum, Oeconomia, 6 (1), s. 35-41.

Pietrzykowski R., 2011, Kształtowanie się cen ziemi rolniczej ze względu na wybrane czynniki użytkowo-rynkowe, Zeszyty Naukowe SGGW w Warszawie. Problemy Rolnictwa Światowego, 11 (26), 4, s. 138-147.

Rozporządzenie Ministra Rolnictwa i Rozwoju Wsi z dnia 14 stycznia 2009 r. w sprawie szczegółowego trybu przeprowadzania przetargów na dzierżawę nieruchomości Zasobu Własności Rolnej Skarbu Państwa (t.j. Dz. U. z 2013 r. poz. 1142).

Stan i perspektywy rozwoju rynku nieruchomości i użytków rolnych w Polsce, 2015, Departament Analiz Makroekonomicznych i Sektorowych BGŻ, Warszawa.

Ustawa z dnia 23 kwietnia 1964 r. Kodeks cywilny (t.j. Dz. U. z 2014 r. poz. 121, z późn. zm.).

Ustawa z dnia 19 października 1991 r. o gospodarowaniu nieruchomościami rolnymi Skarbu Państwa (t.j. Dz. U. z 2012 r. poz. 1187 z późn. zm.).

Well E., 2003, Determinanty kształtujq̨ce cenę ziemi rolnej, Roczniki Akademii Rolniczej w Poznaniu, CCCLVIII, s. 153-168.

Wigier M., 2013, Wpływ polityki rolnej na zmiany strukturalne w rolnictwie, Repozytorium CeON, https://depot.ceon.pl/handle/123456789/6022.

Wilkin J., 2014, Ziemia rolnicza - dobro wielofunkcyjne, Wieś i Rolnictwo, 1 (162), s. 113-121.

Zegar J. S., 2009, Kwestia koncentracji ziem w polskim rolnictwie indywidualnym, Roczniki Nauk Rolniczych, Seria G, 96, 4, s. 256-266.

\section{Summary}

The interest in purchasing agricultural property by both individual farmers and those not previously involved in agriculture has increased after Poland's accession to the European Union. The formation of market prices of agricultural real estate in the recent years has been affected by the limited supply of agricultural land and external conditions related to the functioning of Polish agriculture in the European economy, in particular the system of subsidies granted to agricultural land.

The analysis includes sale of agricultural property from the Agricultural Property Agency (APA) resource (national market) and the private market. The data was obtained from the Central Statistical Office for the years 2005-2013 and the Agricultural Property Agency OT Olsztyn since 2004. Analysis of spatial differentiation concerning the level of transaction prices by regions has been conducted. As confirmed by the results of the research the agricultural real estate market in Poland it is increasingly dependent on external factors. 